\title{
BackChat
}

\section{Our life with Jonathan}

O ur son Jonathan was born in the summer of 94 . The second of three pregnancies, there was nothing to suspect that there might be anything amiss, but this little boy's fate was set in his DNA.

He was born at term with bilateral cataracts and low muscle tone. He had his cataracts removed around l week old and contact lenses fitted a week later. He failed to thrive and was put on a calorie supplement. A false diagnosis of mosaic trisomy 18 was given to us, a laboratory artefact created by the staining process. After a year of severe developmental delay, his kidneys were noted to have Fanconi's syndrome, renal tubular acidosis. The jigsaw finally fitted together and our son was diagnosed with Lowe syndrome; I was the carrier.

What is it like being one of only two families in Scotland with this diagnosis? It has been a huge series of learning curves, not just about Lowe's, but about learning disability in general. We've had to learn to tie together health, social work, and education services and make them work for our son. Who would aspire to have that accomplishment in their CV? We've learned pretty much all you can know about a syndrome and can talk freely about it to others. We've campaigned for change and fundraised for small change. For this beautiful but damaged child we've spent approximately $£ 40000$ over the past ten years-moving regions to get better educational services and going overseas every two years to get good information about his condition. And we would spend all again tomorrow.

We live needing help daily from others but being emotionally isolated from society. We've put up with harangues from people who insist a child cannot possibly own a blue parking badge. $W^{\prime}$ ve listened to well meaning but often quite ignorant advice from strangers about his health care and development. Sometimes the same from health professionals, those people who have presumed to know "all about" Lowe syndrome because they do not have the honesty to tell us, "I've never heard of that before, can you tell me what it is?"

The long waits for equipment, the excuses for lack of services, and the utter drudgery of a decade of nappies; repeat multiple medicines, meals fed to him. "Lenses in" in the morning, "lenses out" at night. Looking for lost lenses in the folds of his sheets, knowing he was more than likely to have eaten it. The triumphs of him learning to walk at age 5, to sign "more drink" at age 8 , the slim-to-nil hope of him toilet training, talking. The double devastation of learning he was on the autistic spectrum and him becoming epileptic. That was a good year. Holding down a screaming dervish of a child as they draw blood, take pulses, blood pressures. Knowing he doesn't care about the pain of the tests, only that he doesn't like being touched. Happy as Larry two minutes afterwards, covered in a mixture of snot, tears, and drool. Driving back and forth for therapy, check-ups, and another milestone missed. Running a bath at 2.30 in the morning because he'd been smearing

Fiona Fisher writes that she hopes her article touches our hearts. That excellent text, "Forfar \& Arneil", tells us that in Lowe syndrome treatment is supportive and parents may benefit from contact with other affected families. I hope those treating multiply disabled children might benefit from considering what Fiona Fisher tells us. poo all over himself and the walls. We use all-in-one pyjamas now. Being caught singing "wheels on the bus" in public, trying to pacify a bored mind. Ignoring the stares as he screams all round the supermarket, it's got good acoustics.

Dutiful devotion and long term love. Trying to nurture the normal development and lives of our two daughters, who may turn out to be carriers too and might have to do this with their sons. Knowing something of his possible future, but not if he'll last the night.

Our son has taught us the real meaning of service, and the triumph of human survival and spirit. We know just exactly who our real friends are, and we are more compassionate ourselves. We are also much less tolerant, of prejudice, ignorance, and discrimination. Even if it doesn't matter to our son, it will matter to someone just like him. Those lives that are vulnerable and reliant for all care.

We know he is a joy and an obligation at the same time. He is emotionally and physically draining. He tests us to the limits and pushes us further than we would have gone without him. We lie at night wondering about his future, if he has a future. He has made us practical and pragmatic, advocates and experts. He has taught us the power of listening and being listened to.

Think of us, as we find our way through our lives, part of a hidden army of family carers with the hardest task in the world and the best reward. Jonathan has truly touched our lives as I hope this touches yours.

Fiona Fisher

Correspondence to: Dr H Marcovitch, Syndication Editor, BMJ Publications; h.marcovitch@btinternet.com 